CATONEM NARRARE:

CHARLES LE BRUN AS READER AND PAINTER OF A STOIC'S SUICIDE

\author{
Eckhard Leuschner*
}

Two pieces of red drapery have been lifted or pushed apart [Fig. 1]. ${ }^{1}$ Just as in a theatrical setting, where the drawing of the curtain marks the beginning of a play, the viewers are introduced to a small but well prepared stage. Originating from an undisclosed source in the upper left, strong light falls onto the bedstall of a bearded man with curly black, slightly greyish hair. The man's nude upper torso is resting on a blank sheet; his energetic bodily features are aptly defined by a strong chiaroscuro. The head has slid down from a cushion, the eyes are closed. His right hand is placed on the page of an open book whose lines are illegible. The man appears to have fallen asleep while reading in his bed.

After just a short while, however, other visual clues reveal the actual state of affairs: the man's left arm is stretched out in a manner quite unusual for sleepers, the colour of his skin is irritatingly pale, the white sheets are bloodstained. The blade of a sword or dagger, likewise covered with blood, is positioned next to the open book in the foreground. Rather than sleeping peacefully, this man is mortally wounded. The shadow of

* My thanks to Heiko Damm and Ulrich Heinen for their critical comments and suggestions on previous versions of this paper, and to Bénédicte Gady for letting me consult her not yet published transcription of the inventory of Charles Le Brun's library.

1 Charles Le Brun, Cato's Suicide, oil on canvas, $96 \times 130 \mathrm{~cm}$, Musée des Beaux-Arts, Arras. Cf. Gareau M., Charles Le Brun. First Painter to King Louis XIV (New York: 1992) 164165 (with older reference until 1963), and Baligand F. (ed.), La peinture française aux XVll et XVIIl ${ }^{e}$ siècles: Dunkerque, Valenciennes, Lille, exhibition catalogue, Trésors des Musées du Nord de la France 4 (Lille: 1980) 49. Both publications leave unmentioned another version of the composition, $108 \times 147,5 \mathrm{~cm}$, that surfaced in the Paris art trade in 1988: The Burlington Magazine 130 (September 1988) XXIII (advertisements). See also Gady B., L'ascension de Charles Le Brun. Liens sociaux et production artistique (Paris: 2010) 162 and OberreuterKronabel G., Der Tod des Philosophen (Munich: 1986) 112, and Mai E. - Repp-Eckert A. (eds.), Triumph und Tod des Helden, exhibition catalogue (Cologne: 1987) 178 (cat. no. 7); for some general introductory remarks on Renaissance and Baroque representations of Cato's death in comparison with images of other (ancient) suicides cf. Brown R.M., The Art of Suicide (Chicago: 2001) 93-100. 


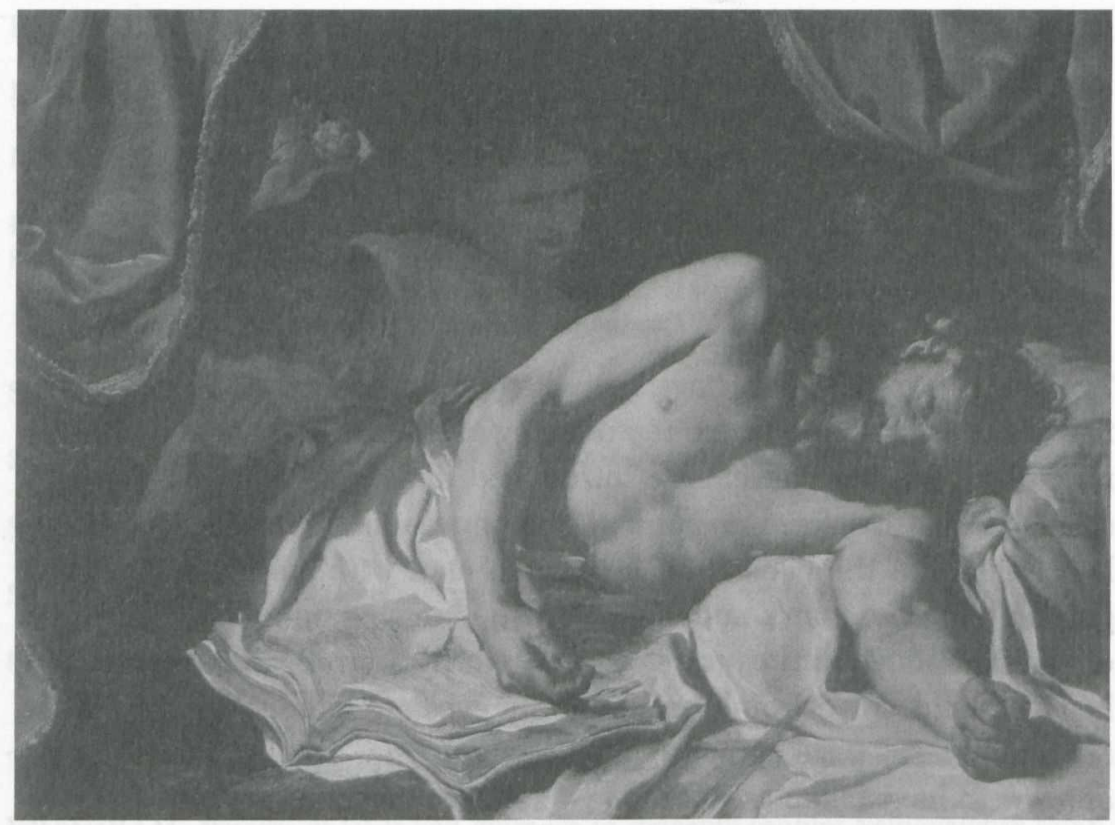

Fig. 1. [CoL. PL. 12] Charles Le Brun, Death of Cato, 1645-1646. Arras, Musée des Beaux-Arts.

his right arm hides almost all traces of the wound in his stomach that (as is implied by the position of the dagger) was self-inflicted. In a dark background space defined by the bedpost behind the man's head, two further persons can be made out whose reactions to what they see are divided between deep grief and hectic attempts at the man's rescue. In terms of composition, the artist has carefully focused the beholder's attention on the head of the man by combining the painting's oblong format with the almost indiscrete close-up effects of the lifted curtain, the theatrical lighting and the various diagonals indicated by the blade, the open book, and the movements of the two persons in the dark background.

According to his earliest biographers, Charles Le Brun (1619-169o) painted this picture in Lyon, where he spent some time on his return from a three year stay in Italy. ${ }^{2}$ Nothing is known about the person who com-

${ }^{2}$ Nivelon C., Vie de Charles Le Brun et description détaillée de ses ouvrages. Édition critique et introduction par Lorenzo Pericolo (Geneva: 2004) 122. Cf. also Chomer G., "Charles Le Brun avant 1646: Contribution aux problèmes de sa formation et de ces œuvres de jeunesse", Bulletin de la Société de l'histoire de l'art français (1977) 93-107, esp. 100. Regarding the picture's date, Chomer points to the biography of Le Brun compiled by Saint- 
missioned or first owned it. The paintings' subject is the Suicide of Cato Minor (95-46 b. C.), also known as Cato Uticensis, an important exemplum virtutis of stoic philosophy during the days of the Roman Empire. ${ }^{3}$ Especially in Seneca's Epistulae morales ad Lucilium, Cato is frequently cited and referred to as a role model for the student who is advancing in Stoic philosophy, i.e. the proficiens or $\pi$ poxó $\pi \tau \omega \nu$. Such didactic functions, however, had the side effect of simplifying or blurring the historic truth.

The last years of Cato's life were famously overshadowed by the agony of the Roman Republic. Defining his political agenda from a mixture of republican ideals and stoic convictions, Cato Minor acted as leader of the optimates in the Senate. Unimpressed by all threats, he advocated for the traditional order of the Roman state and strict obedience to the constitution at a time when civic values were undermined by the personal ambitions of Pompeius, Crassus and Caesar. When the Civil War broke out, Cato decided to become an ally of Pompeius and accepted military tasks in the latter's campaign. After the defeat of Pompeius at Pharsalos in 48 b. C., Cato (who had not been involved in the battle) managed to evacuate his own soldiers and the remaining parts of the republican army to Utica in Northern Africa. When Caesar threatened to besiege the town and no hope of a successful defence remained, Cato organised the disembarkation of his troops, but stayed in situ and strictly refused to beg for Caesar's mercy, because he denied the latter's legitimation to officially grant it.

The most important source for Cato's career and death is his vita in Plutarch's Parallel Lifes (ca. 100 a. C.). ${ }^{4}$ The Greek author describes at great length the last hours of a man who had come to the conclusion that only suicide could secure his personal integrity and freedom. Plutarch's

Georges G. de, Mémoires inédits sur la vie et les ouvrages des membres de l'Académie royale de peinture et de sculpture (Paris: 1854), vol. I, 7, and compares the picture with Le Brun's lost 'Pietà Séguier' (painted in Rome in 1645) that is partly documented in a drawing by or after the artist in the Art Institute of Chicago.

${ }^{3}$ For the biography and reception of Cato Minor cf. Fehrle R., Cato Uticensis (Darmstadt: 1983), Goar R.J., The legend of Cato Uticensis from the first century B.C. to the fifth century A.D. (Brussels: 1987), and Besslich B., "Cato als Repräsentant stoisch formierten Republikanertums von der Antike bis zur Französischen Revolution", in Neymeyr B. Schmidt J. - Zimmermann B. (eds.), Stoizismus in der europäischen Philosophie, Literatur, Kunst und Politik. Eine Kulturgeschichte von der Antike bis zur Moderne (Berlin-New York: 2008), vol. I, 365-392.

4 Plutarch, Vitae Parallelae, Cato Minor, 67-70. Cf. Fehrle, Cato Uticensis 1-21 and 276278 , esp. n. 178 , where the author lists 'ohne Anspruch auf Vollständigkeit' a considerable number of literary versions of Cato's death by ancient writers. 
account betrays sympathy with the Roman, but he does not omit (rather on the contrary: he stresses) the many difficulties Cato was facing after he had told his friends that he was contemplating suicide. In the evening of the same day, his sword that previously used to hang next to his bed was missing, and when he insisted to have it back, his servants would not obey his order. Cato's son tearfully implored him not to carry out his plan, and his philosophical companions brought forward all kinds of arguments against self-inflicted death. Cato, however, could not be talked out of it. He regained his sword by pointing out that, should he really wish to kill himself, he could easily hold his breath or bang his head against the wall. For most of the same night, Cato's behaviour gave no cause for further anxieties: he read Plato's Phaidon (on the soul's immortality), ${ }^{5}$ at times inquiring about the state of the disembarkation (which was almost finished) or falling asleep. When the next day was dawning and the familia felt almost sure that the immediate danger was over, Cato seized his sword and cast it into his stomach. As he fell to the floor, he overturned a large tablet serving for arithmetic calculations ( $\dot{\alpha} \beta \dot{\alpha} x$ เov) that was leaning against the bed, thus alarming the servants: His attempted suicide was discovered, and a doctor saved his life by bandaging the wound. A little later, however, Cato tore open the bandage, pulled out his guts with his own hands and thus managed to finally kill himself.

Before long, the historic personality of the late Cato Uticensis was reduced to a few memorable deeds and philosophical convictions. ${ }^{6}$ The rhetoric teachers of the imperial age went so far as to turn his death into a standard motif for young students who had to learn by heart and declamate ad nauseam pompous 'farewell speeches of the dying Cato'. ${ }^{7}$ But in spite of the fact that the heroic end of the Uticensis had long since been banalised by literary routine and didactic exercises, major authors such as Seneca continued to praise Cato as the first and foremost Roman personification of the Stoic ideal. Seneca's 24th Letter to Lucilius, as a matter of fact, contains the most important evocation of Cato's suicide in ancient literature next to that of Plutarch.

${ }^{5}$ Plato's Phaidon had a certain fame as the ideal book for the preparation of a suicide, e.g. in the 23th Epigram of Kallimachos.

6 Fehrle, Cato Uticensis 22.

7 Fehrle, Cato Uticensis 25, who cites Persius, Sat. 111,44-47: 'Saepe oculos, memini, tangebam parvus olivo/ grandia si nollem morituri verba Catonis/discere, non sano multum laudanda magistro/ quae pater adductis sudans audiret amicis'. 
In his 24th Letter, Seneca reacts to the situation of his pupil Lucilius, who is worried about the results of a lawsuit that has been forced onto him (Seneca, Epistulae 24,1). Seneca has already given advice for similar cases (cf. Seneca, Epistulae morales ad Lucilium 13 and 14): one should always remain full of hope and refrain from unnecessarily anticipating future suffering (ibid. 24,2). In the present circumstances, however, Seneca announces to lead Lucilius on a different way to 'securitas'. ${ }^{8}$ Avoiding anxiety ('sollicitudo') requires to prepare oneself for the moment in which one's fear eventually becomes reality and to analyse both the feared object and the nature of one's fear. ${ }^{9}$ Such calculations will invariably demonstrate that the reality of whatever can be feared is less impressive than one's previous fear of it. In order to deal with particular objects of fear, one should look out for role models ('exempla') and procede as follows: imagine the worst kinds of harm that can be done to you and then find one of the many famous despisers ('contemptores') of each scenario (ibid. 24,3-11). Citing several examples of this technique, Seneca draws the conclusion that even the biggest object of fear, death, is hardly worth the trouble - on the contrary, death is a benefit because it can always be brought about on your own initiative and thus diminishes fear of all harm in life (ibid. 24,11/12). Lucilius should therefore feel 'securus' in the face of his adversary's threats. Summarising his position, Seneca adhorts his pupil: Expect the best ('aequissimum') outcome of your lawsuit, but be always prepared for the worst ('inaequissimum')!

In the remaining part of the 24th Letter, Seneca further elaborates on particular aspects ${ }^{10}$ of his previous general suggestion to always analyse both the fearful object and the nature of one's own fear. According to him, fear of pain or death can arise in us because we are looking at the outward appearance ('pompa') rather than at the essence of things (ibid. $24,13 / 14)$. Lucilius, as a student of stoic philosophy, may already have realised this, but such knowledge needs to be translated into action whenever this should become necessary (ibid. 24,15). A heavy blow such as illness, poverty, exile or imprisonment can be endured if you are prepared for it, and death, purportedly the worst of all blows, is also the end of all harm

8 There is no reason to conclude that Seneca herewith declared that his previous suggestions were entirely wrong - cf. Cancik H., Untersuchungen zu Senecas epistulae morales (Hildesheim: 1967) 74 .

9 Seneca's term 'sollicitudo' appears to have had exactly the opposite meaning of 'securitas' (Epistulae 92,3: 'Quid est beata vita? securitas et perpetua tranquillitas'); cf. Hadot I., Seneca und die griechisch-römische Tradition der Seelenleitung (Berlin: 1969) 128.

10 Cf. Maurach G., Der Bau von Senecas Epistulae Morales (Heidelberg: 1970) 99. 
(ibid. 24,16/17). Epicurus has revealed the terrors of Hades to be old wives' tales. ${ }^{11}$ Death is either the ultimate limit or the beginning of something better (ibid. 24,18) - not to mention the fact that we are always dying ('cotidie morimur'): not only in the last hour, but in every hour of our life (ibid. 24,19-21).

Summing up the intentions of Seneca's strategy against fear of exile, imprisonment, pain, death and other forms of suffering, two important aspects can be distinguished:

1. A life previously burdened with fear will be liberated from 'sollicitudo' as soon as all possible reasons for fear have been analysed or rationalised, whereby 'securitas' is achieved.

2. Whenever exile, imprisonment, pain or death are imminent, premeditation has prepared one to cope with them and to prove the seriousness of one's stoic attitude ('effectu probare', ibid. 24,15).

Only the sum of both aspects is enough to fully characterise Seneca's philosophical struggle against fear. ${ }^{12}$ This applies especially to the worst reason of fear, death, the suppression of which requires combining elements of 'ars vivendi' with 'ars moriendi'. ${ }^{13}$ 'Exempla' were at the heart of his concept, as they demonstrate how easily fear, especially fear of death, can be overcome. In addition to that, the continuous study of personified examples of manly suffering, i.e. of famous despisers ('contemptores') of imprisonment, pain, death etc., was intended to provide preparatory training for the case of need. ${ }^{14}$

Seneca's panorama of despisers (Epistulae $24,3^{-8}$ ) is arranged in a kind of literary crescendo. Starting with a small section devoted to 'exile', in which P. Rutilius Rufus and Caecilius Metellus Numidicus are cited, he proceeds to deal with the more serious reasons for fear, 'imprisonment' and 'pain':

11 Sentences such as this demonstrate that Seneca was not really interested in speculations about the soul's life after death. Cf. Eckert H.H., Weltanschauung und Selbstmord bei Seneca und den Stoikern (PhD Thesis, Tübingen: 1951) 97.

12 Regarding fear of death, both aspects are treated with varying intensity in the Letters to Lucilius, and 'ars vivendi' and 'ars moriendi' are discussed separately, cf. e.g., Seneca, Epistulae 54 (life made easier by meditation of death, first aspect prevailing) and Epistulae 77 (= suicide as a means to secure or achieve 'libertas', second aspect prevailing).

13 Cf. Seneca, Epistula 6,5: 'longum iter est per praecepta, breve et efficax per exempla'. Seneca tended to combine particular examples of suffering with particular despisers, $\mathrm{cf}$. e.g. Seneca, Epistula 67,7 and De providentia 3,4 .

14 'Singula ista constitue et contemptores eorum cita, qui non quaerendi sed eligendi sunt', Seneca, Epistula 24,3. 
Socrates led philosophical discussions in his prison cell and refused to leave even when he was guaranteed a secure escape; he stayed on because he wished to free people from the two gravest reasons for fear: imprisonment and death. Mucius [Scaevola] put his hand into the fire. It is painful to be burned: but how much more painful must it be if you suffer this out of your own free will! Here you see a man who is neither intellectual nor prepared by any kind of philosophical training against pain and death, who punished himself for having failed [sc. to kill Porsenna] just out of his own military prowess. Watching the flesh of his right hand dissolve and drop down into the hearth of the enemy, he stood firm and did not withdraw the almost nude bone of the hand until the enemy himself withdrew the fire. He could have ated luckier in this camp, but could hardly have been more courageous. Behold, how much more intensely virtue copes with danger than cruelty can impose it: Porsenna more easily forgave Mucius for having intended to kill him than Mucius forgave himself for having failed to do so.

In Seneca's 24th Letter, the scope of examples grows in proportion with the intensity of suffering. ${ }^{15}$ The philosophical attitude of the imprisoned Socrates is characterised at greater length than that of the two exiled politicians mentioned above. His example, moreover, is special among all 'contemptores' in Epistulae 24 in the sense that Socrates is the only despiser who, according to Seneca, explicitly regarded his actions in relation to their didactic effect on others. This element of reflexion marks an important contrast to the next example, the heroic self-mutilation of Scaevola ('Mucius ignibus manum imposuit'), whose action was motivated by 'robur militare' rather than by any kind of philosophical attitude. The account of Scaevola's spontaneous action in the face of the enemy with all its unsavoury details opposes the 'natural' bravery of the Romans to the philosophical nature of the Greek as represented by Socrates.

Having cited these examples, Seneca anticipates an objection of Lucilius: 'These fairy-tales have been told over and over again in all rhetoric schools. If it comes to despising death, you will probably fall back on the old story of Cato [“Catonem narrare"]'! Seneca, apparently unimpressed, continues by doing just that: he begins to narrate the old story of Cato:

Why shouldn't I tell how he [= Cato] read Plato's book in that last night, his head placed next to the sword? In his desperate situation, he made use of these two instruments, the first for wanting to die, the latter for being able to. Therefore, having put in order his personal affairs (as much as this could be done under such circumstances), he took this action to be inevitable, as he did not wish to allow anybody either to kill or to save him; and he drew

15 Cf. Maurach, Der Bau von Senecas Epistulae Morales 98, no. 81. 
the sword that until then he had spared from all blood, and said: 'Nothing, o fate, did you achieve by obstructing all my plans. I did not fight for my personal freedom but, rather, for that of my country, and I did not do politics with such tenacity to live myself as a free man but, rather, as a free man among free men. Now that all hope for mankind is lost, Cato will be safe'. Having said this, he inflicted the deadly wound to his body. When it was bandaged by the doctors, he had less blood and less strength, but still the same amount of courage, and he dug - not so much angry with Caesar anymore but angry with himself - his naked hands in the wound, thus releasing, or rather: throwing out his noble soul that despised all power. ${ }^{16}$

Why did Seneca insist on the somewhat worn example of Cato Uticensis? The answer is easy: he could not do without him. Only in the 'exemplum Catonis', the perfect Roman citizen was combined with the ideal Greek sage, i.e. Scaevola and Socrates had a single persona. In Cato, old-style virtue combined with a reflected Stoicism created a hero who was totally unafraid of being put to the test in extremis. He, if anybody, passed the test of the 'effectu probare' by combining 'arma' and 'litterae' in the most elementary sense. In addition to that, Cato's suicide succeeded only after a second attempt - a fact that secured this master of suffering an almost unique position (only to be surpassed by Seneca himself, who, when committing suicide, needed even more attempts). ${ }^{17}$ The story of Cato, moreover, especially suited the author's Stoic pedagogy in the sense that it had a strong 'visual' quality permitting to illustrate an inner attitude by means of historic or physical events. It comes as no surprise that the relation of the proficiens to his Stoic role model has been described as that of a selfassimilation by means of mimicry, i.e. the imitation of and identification with an image..$^{18}$

In Seneca's philosophical system, the example of Cato was above all intended to teach the art of dying (discere mori), which means that it had to be impressive enough to successfully support the long and difficult process of losing one's fear of death. ${ }^{19}$ This function of the Uticensis is

16 Seneca, Epistulae 24,6-8.

17 Cf. Seneca, De providentia 2,12: 'Non fuit dis immortalibus satis spectare Catonem semel; retenta ac revocata virtus est, ut in difficiliore parte se ostenderet, non enim tam magno animo mors inicitur quam repetitur'.

18 'So wird verständlich, warum Seneca wieder und wieder die Gestalt des Weisen schildert, oft mit den Stilmitteln einer flammenden Beredsamkeit. Er bemüht sich, eine innerseelische Haltung zu beschreiben, die sich nur schwer von außen verständlich machen lässt, die man nur nacherleben kann, wenn man in sich, von einem Bilde ausgehend, eine mimikry-artige Angleichung erzielen kann'. Grimal P., Seneca. Macht und Ohnmacht des Geistes (Darmstadt: 1978) 291.

19 Cf. Seneca, Epistulae 30,17: 'Tu tamen mortem ut numquam timeas, semper cogita'. 
especially clear in Epistulae 24, where Seneca struggles to re-propose and re-establish the personality of someone he considered to be the perfect despiser of death. In his Cato passage, the author employed an almost provocative wealth of rhetorical means because he wished to lay bare the essential message of a historic event that had suffered from trivialisation in recent years. Even though Seneca had no other means at his disposal than the rhetoric schools, he accepted the challenge and created an unusually intense version of the novissima verba Catonis. Seneca's double intention to break up the rhetoricised routine of Cato's suicide and to create an updated version of his hero's story makes itself felt in a fact already mentioned above: the account of Epistulae 24 omits all reactions of others. Directing the reader's full attention to the protagonist, he progresses from certain allusions (such as the 'yet' pure sword) to an ultimate, affectional part in which drastic brutality prevails ('nudas in vulnus manus egit'). Both Cato's monologue and the omitted reactions of others create an impression of heroic isolation, implying that even during the physical hardships of his self-inflicted death, Cato kept his personal dignity. In trying to achieve this - almost impossible - double effect, Seneca went as far as his literary means permitted. ${ }^{20}$

When painting his picture today in Arras, Charles Le Brun appears to have aimed at creating a similar intensity in the representation of the Stoic hero. In this work, the 'exemplum Catonis' is literally brought within the spectator's reach. In order to achieve this close-up effect, the French artist took recourse to painterly devices of the Caravaggist School that was then - in the mid-1640s - well-established and offered valid stylistic options, even though it began to look slightly old-fashioned. There can be little doubt, however, that Le Brun intended to produce more than just a curious piece of history painting. Instead, he used the physical drama as defined by the oblong format, the suggestive chiaroscuro and the system of diagonals leading up to the hero's head to convey a philosophical attitude or inner conviction. In doing so, Charles Le Brun (or his advisor) must have consulted a literary source with a closely related approach.

20 Seneca himself realised that his rhetoric talent threatened to interfere with the intended 'updating' of his stoic hero. He therefore pointed out (Seneca, Epistulae 24,9) that he did not intend 'ut ingenium exerceam' (in this sense, 'ingenium' was a negative expression; cf. Seneca, Epistulae 108,23: 'qui propositum adferunt ad praeceptores non animum excolendi sed ingenium'). As far as the despising of death was concerned, other examples were at hand. Seneca pointed to Scipio, who had led a less successful life than Cato but who died heroically, and he then mentions that in his own days a lot of persons 'qui mala sua morte praeciderint'. 
Even though he had several ancient and Renaissance texts dealing with the death of Cato Uticensis at his disposal, the basic choice remained that between Plutarch's Vita of Cato and Seneca's 24th Letter to Lucilius. The latter is the likelier model, as Plutarch's detailed account and the sources depending on him focus not so much on the hero himself but on the events leading to the self-killing and on the various reactions of Cato's family and friends.

Any confrontation of the Arras painting with the textual and visual traditions of the theme has to begin with defining the exact moment chosen by the artist for the representation of Cato's death. As far as we can tell, Le Brun's painting depicts the phase immediately after Cato's first, unsuccessful suicide attempt. He has already lost a lot of blood and appears to be unconscious; two agitated persons, probably members of his household, have just found him. The man represented further to the right touches Cato's head, only the thumb of his hand is visible. He must be the doctor who will bandage the wound. Surprisingly, any attempt to identify this moment in Seneca's Epistulae 24 is bound to fail. In this text, the discovery of the wounded Cato, of all events, is unmentioned. Seneca's short sentence 'Inpressit deinde mortiferum corpori vulnus' is followed by the ablativus absolutus 'Quo obligato a medicis' that establishes a syntactical connection but bridges a considerable chronological gap. ${ }^{21}$ Employing similar brevity, Seneca has previously started his literary digression: 'Quidni ego narrem ultima illa nocte Platonis librum legentem posito ad caput gladio'? ${ }^{22}$ In just one sentence, he says it all: echoing the last words of Lucilius' objection ('narrabis' - 'narrem'), he mentions the precise time ('ultima illa nocte'), his hero's name and current occupation ('Platonis librum legentem'), the fatal instrument and its place ('posito ad caput gladio'). As soon as this exposition is complete, the reader has taken, so to speak, his seat in front of Cato's bed. Seneca's object is a maximum immediacy of the 'exemplum Catonis', and Le Brun may well have attempted to achieve something similar.

Seneca's text, morevover, is the only written source in which the book and the sword are paralleled as two equally important instruments of the stoic hero's suicide. ${ }^{23}$ In Le Brun's painting, the same parataxis serves as a kind of introduction to the entire picture: starting at these two objects,

21 Seneca, Epistulae 24,8.

22 Seneca, Epistulae 24,6.

23 Le Brun's interest in Seneca is also documented in his 'Le tombeau de Sénèque' (Musée du Louvre, Paris, R.F. 1998-2), that served as a model for an engraving by Gilles 
the beholder directs his attention to the body and face of Cato. The sharp contrast of the white linnen and the blood stains (with the blood metonymically representing the wound) is likewise closely related to Seneca's narrative who mentions that Cato had kept his sword 'until then free of all blood' ('usque in illum diem ab omni caede purum'), thus evoking the contrary of such aseptic purity: before long, the shining blade will be covered with blood. Although Le Brun could hardly invent a direct equivalent to Cato's dramatic monologue in Epistulae 24 stemming from Seneca's experience as an author of tragedies ('Nihil egisti, fortuna, $[\ldots]$ '), there is a theatrical atmosphere in the picture as well: it is enough to mention the red curtains and the chiaroscuro.

Not surprisingly, the inventory of Charles Le Brun's library drafted after the artist's death in 1690 mentions French translations of both the Vitae Parallelae of Plutarch and Seneca's Letters to Lucilius, the first by Jacques Amyot, the latter by Mathieu de Chalvet. ${ }^{24}$ Although more research on the libraries of French 17 th century artists is needed, the presence of such titles in Le Brun's inventory - along with translations or partial editions of Thukydides, Virgil, Ovid, Livy, Flavius Josephus, Quintus Curtius, Pliny the Younger, Philostrate and Tacitus - indicates that his library contained more than just the usual reference on art history, iconography and architecture owned by other painters. ${ }^{25}$ These books clearly point to the artist's

Rousselet - cf. Charles Le Brun 1619-169o, peintre et dessinateur, exhibition catalogue Paris (Paris: 1963) 30, cat. no. 13 .

${ }^{24}$ Inventaire après décès de Le Brun, Paris, Arch. nat., Min. centr., LXV, 126 (Rés. 193), dated 2 March 1690 (discovered by Roger-Armand Weigert and published in excerpts as: Weigert R.-A., "L'inventaire après décès de Charles Le Brun, premier peintre de Louis XIV (169o)", Gazette des Beaux-Arts 96 (1954) 339-354, 371-376; a complete transcription will be published by Bénédicte Gady in the Archives de l'art français), p. 120 (28 April 169o, books in the 'maison du fossé des pères de la doctrine chrestienne'): 'Item les œuvres de Sénec par Chalvet en grand papier prisé trois livres. Ci III lt.' [Les CEuvres de L. Annaeus Seneca, mises en françois par Mathieu de Chalvet (...), Paris, A. Langelier, 1604, in-fol.] 'Item les œuvres de Plutarque 4 thomes prisé huit livres. Ci VIII lt.' [Les CEuvres morales et meslées de Plutarque, (...) traduites de grec en françois par Jacques Amyot (...), Lyon, P. Frelon, 1615,2 t. en 4 vol., in- $8^{\circ}$ ] p. 124 (2 May 169o, ibid.): 'Item un paquet de quatorze dont plusieurs thomes de Sénec tant innoctavo qu'in douse prisé' [precise bibliographic details unclear].

25 E.g., there is a much smaller quantity of ancient texts, both originals or translations, in the inventories of Claude Déruet (Jacquot A., "Notes sur Claude Deruet, peintre et graveur lorrain, 1588-166o", Réunion des Sociétés des Beaux-Arts des départements 18 (1894) 763-943) and Jacques Stella/Claudine Bouzonnet Stella (Thuillier J. (ed.), Jacques Stella 1596-1657, exhibition catalogue (Paris: 2006) 253-257). 
extensive activities in the field of history painting and his interest in its theoretical foundations. ${ }^{26}$

It can be safely assumed that Le Brun developed a taste for subjects from ancient literature, history and philosophy at an early stage of his career. If nobody else, his mentor Poussin must have directed his attention to 'erudite' themes. The young Le Brun, therefore, when preparing the Arras picture, almost certainly knew some of the previous painted versions of the Death of Cato (see below), but he hardly conceived his own painterly solution without being aware of the two most important literary versions of the event. Confronting the detailed account in Plutarch with Seneca's condensed and intensified version in Epistulae 24, Le Brun decided to adopt the latter. This explanation remains valid even though the artist decided to add two figures unmentioned by Seneca in the dark background of his painting, intending either to further indicate the exact moment depicted or to stress the contrast between Cato's heroic suffering and the servants' 'unphilosophical' attitude of agitation or despair. ${ }^{27}$

A comparison of the Arras picture with other 17th century representations of Cato's death helps to clarify the artistic means of Le Brun's invention. Leaving aside a few examples from the Cinquecento and by neo-classicist painters active around $1800,{ }^{28}$ the Cato theme in art was a typical phenomenon of the Baroque period. ${ }^{29}$ An etching by Pietro Testa [Fig. 2], dated 1648 (i.e. two years before the artist's suicide), is a good case in point. Certain details such as the tablet covered with geometrical calculations and the large number of bystanders point to the influence of Plutarch's narrative, but the wording of the print's legend demonstrates that Testa or his advisor must have been familiar with Seneca's Epistulae 24

26 In 169o, Le Brun's library consisted of several hundred volumes. Apart from works of literature (Tasso, Montaigne), geography, philosophy and theology, he also owned the kind of books usually associated with an artist's library of the period. Among others, his inventory lists editions of Vitruvius and Palladio, Juan Bautista Villalpando's In Ezechielem Explanationes, the Anatomia by Andreas Vesalius, Joachim von Sandrart's Academia todesca, Otto van Veen's Emblemata Horatiana, Claude Perrault's Ordonnances de cinq espèces de colonnes and Roland Fréart's Traitté de la peinture de Léonard de Vinci.

${ }^{27}$ Le Brun (unlike Poussin in the 'Germanicus', cf. Montagu J., The Expression of the Passions: The Origin and Influence of Charles Le Brun's Conference sur l'expression générale et particulière (New Haven-London: 1994) 6o) did probably not use the poor visibility of the two faces in the manner of the ancient painter Timanthes, i.e. to suggest especially strong emotions.

28 Cf. Oberreuter-Kronabel, Der Tod des Philosophen 110.

${ }^{29}$ Geiger J., "Giambettino Cignaroli's Death of Cato and of Socrates", Zeitschrift für Kunstgeschichte 59 (1996) 270-278, esp. 270-271. 


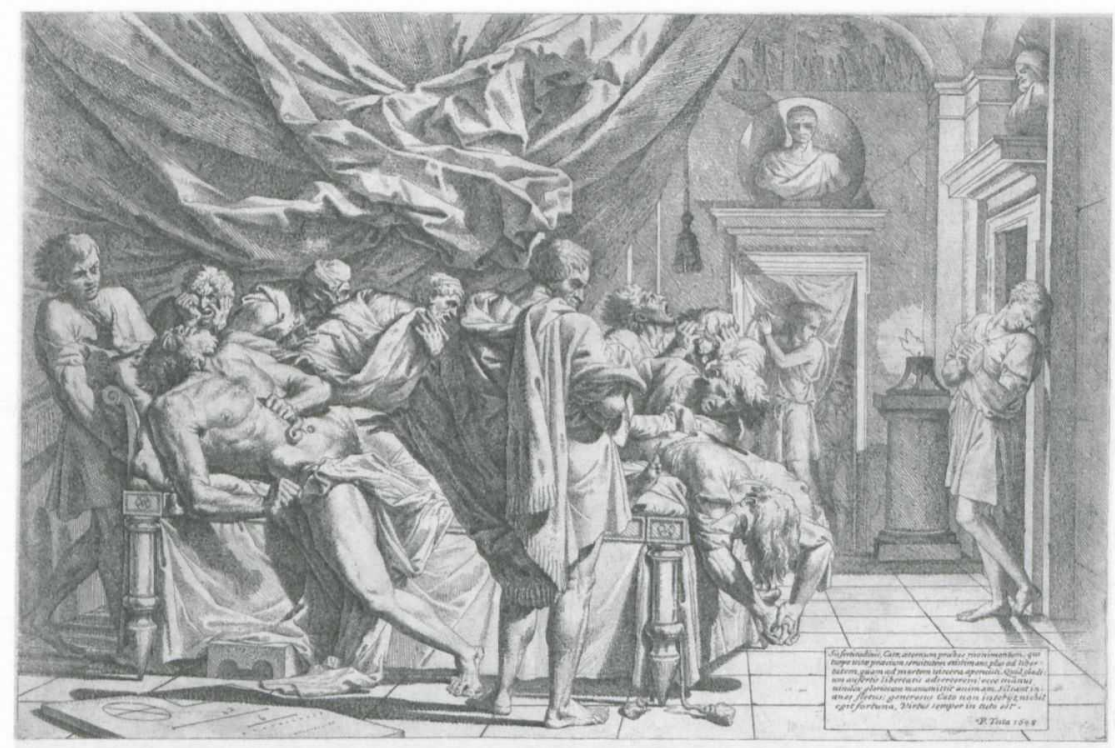

Fig. 2. Pietro Testa, Death of Cato, 1648. Radierung. (C) Trustees of the British Museum.

as well. ${ }^{30}$ In Testa's etching, the Uticensis has already successfully carried out his second attempt. By positioning Cato's dead body on the bed amid a large group of bystanders and mourners, the artist represented the Stoic hero in the manner of an ancient tragedy that would have been incomplete without the strong emotions displayed by his friends and family.

Several other 'Death of Cato' paintings were made prior to Le Brun's picture and Testa's etching, e.g. those by Joachim von Sandrart, ${ }^{31}$ Matthias Stomer $^{32}$ and Gioacchino Assereto ${ }^{33}$ [Fig. 3]. All three artists were

30 Inscription: 'Sic fortitudinis, Cato, aeternum praebes monimentum, qui / turpe vitae praecium servitutem existimans, plus ad libert- / tatem, quam ad mortem viscera aperuisti. Quid gladi- / um aufertis libertatis adsertorem? Ecce manus / vindex gloriosam manumittit animam. Sileant in- / anes fletus: generosus Cato non interiit, nichil / egit fortuna, Virtus semper in tuto est. / P. Testa 1648'. The influence of both Plutarch's and Seneca's text on the legend of this print has already been pointed out by Cropper E., Pietro Testa 1612-1650. Prints and Drawings, exhibition catalogue (Aldershot: 1988) 249-256.

31 For Sandrart's picture cf. Olivier Bonfait in Académie de France a Rome (ed.), Roma 1630. Il trionfo del pennello, exhibition catalogue (Milan: 1994) 220-227.

32 On Stomer's 'Death of Cato' ('Catania') see Fischbacher F., Matthias Stomer. Die sizilianischen Nachtstücke (Frankfurt: 1993) 90.

33 Cf. Sibylle Luig, in Contini R. (ed.), Pracht und Pathos: Meisterwerke der Barockmalerei aus dem Palazzo Bianco in Genua, exhibition catalogue (Berlin-Mailand: 2003) 102-103, cat. no. 21 . 


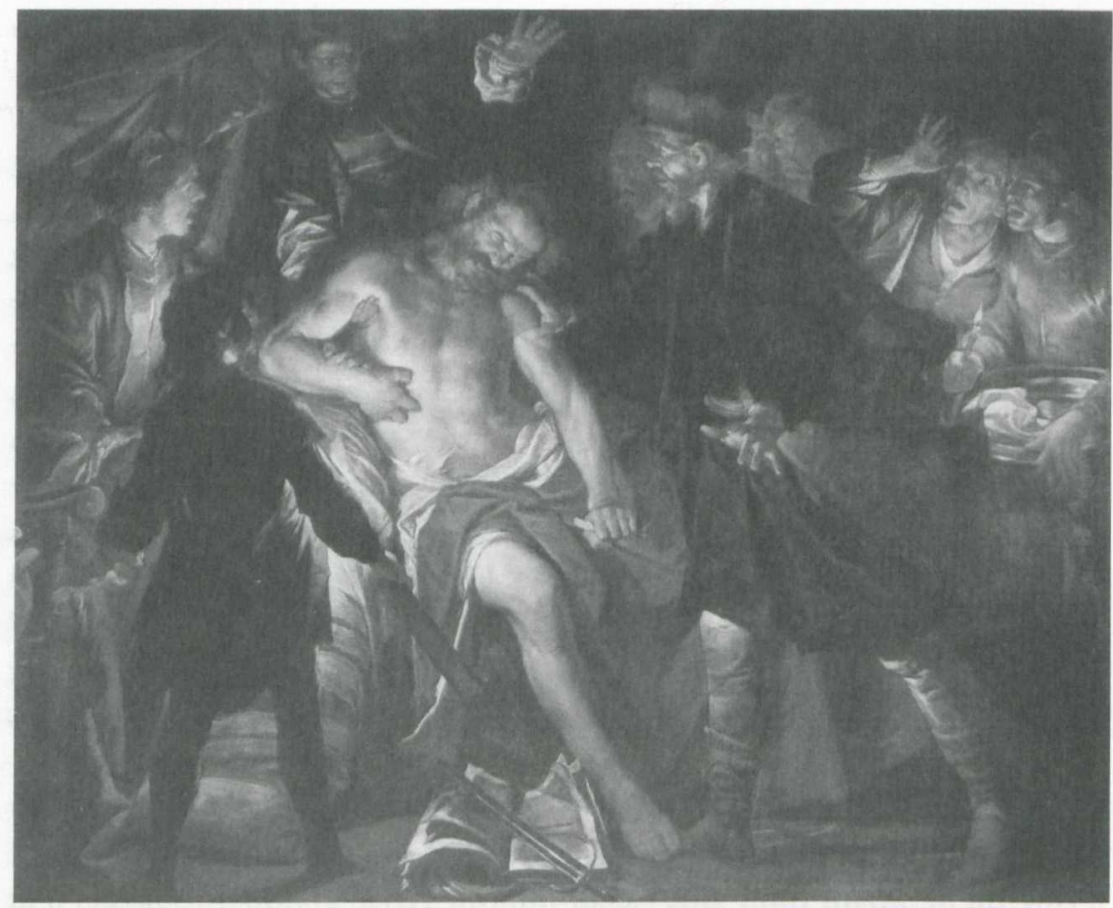

Fig. 3. Gioacchino Assereto, Death of Cato. Genoa, Palazzo Bianco.

attracted by the dramatic possibilities of the theme, and they may also have looked for an iconographic variant of the 'Death of Seneca' whose fortuna in painting had been established a few years earlier by Peter Paul Rubens. ${ }^{34}$ Following Sandrart's installation of the Stanza dei Filosofi in the Palazzo Giustiniani in Rome (1635), a room hung with large pictures representing the deaths of famous ancient philosophers such as Socrates, Cicero and Seneca, such paintings were en vogue all over Italy and in the rest of Europe. Sandrart's own 'Death of Cato' of ca. 1630/1631, today in Padova, is an elaboration of a 'Death of Seneca' by the painter's Dutch teacher Gerrit van Honthorst whose restrained Caravaggist manner it echoes. ${ }^{35}$ Assereto's 'Death of Cato', by contrast, in which the Stoic hero is

${ }^{34}$ Cf. Hess G., "Der Tod des Seneca: Ikonographie - Biographie - Tragödientheorie", Jahrbuch der Deutschen Schillergesellschaft 25 (1981) 196-228.

35 Sandrart mentions the picture in his own Vita (Sandrart Joachim von, Teutsche Academie (Nürnberg, Johann-Philipp Miltenberger: 1675) vol. III, 75): 'Also ward von ihm gebildet der Cato von Utica, wie derselbe/ nach empfangenem Stich/vom Bette zur Erden gestürzet/ und von Demetrio seinem Sohn/ auch von andern Römischen Soldaten/ aus 
surrounded by a bunch of wildly gesticulating companions and servants, resembles a turbulent genre scene created in the most intense version of Caravaggism. In spite of such differences in attitude, the literary model of both paintings, just as was the case with Testa, appears to have been Plutarch. Following Sandrart, Stomer and Assereto, artists as Giovanni Battista Langetti, ${ }^{36}$ Luca Giordano ${ }^{37}$ and others painted similar pictures in which Cato is usually still alive, but doing all he can to kill himself by tearing open the wound. These compositions responded to the period's taste for drama and emotional intensity in history painting, but they may not have been based on a close reading of ancient textual sources nor were they intended to serve as an 'exemplum virtutis'.

It goes without saying that, as far as visual models for the depiction of the 'Death of Cato' are concerned, even the first Seicento painters representing the scene did not limit themselves to consulting Plutarch or Seneca - rather, they looked for inspiration from existing visual schemes. It comes as no surprise, therefore, that several Baroque representations of dying philosophers closely resemble images of the 'Death of the Virgin', for example the famous altarpiece by Caravaggio for Santa Maria della Scala, today in the Louvre. ${ }^{38}$ The Apostles assembled around the deathbed of Mary and depicted in various states of despair appear to have set the example for most of the period's pictures representing the Suicide of Cato amid expressions of grief and bewilderment of friends and family.

This observation does not imply, however, that the Caravaggisti were incapable of consulting textual sources. For example, at least one key element in Assereto's painting [Fig. 3], the 'still life' in front of Cato's feet consisting of the open book and the sword placed upon it ('arma et litterae'), must have been derived from Seneca's Epistula 24. Le Brun,

seinem Blut aufgehebet worden: Alles in einer belieblichen Nacht/ mit den natürlichsten Affecten/ und einspielung des künstlichen Liechts auf den nackenden Leib und der anwesenden eiserne Harnisch; zu hohem Ruhm und bästem Nachklang/ bey den verständigen Kunst-Liebhabern'.

36 E.g. in the Kunsthistorisches Museum, Vienna, inv. no. 5642.

37 Several versions of the subject by Giordano or his workshop exist, e.g. in the Musée des Beaux-Arts of Chambéry and in the museum of Chalon-sur-Saône; cf. Ferrari O. - Scavizzi G., Luca Giordano. L'opera completa (Naples: 1992) 822, cat. no. A648. In one of the pictures, Giordano has combined the sword and the book in a manner reminiscent of Assereto and Le Brun.

38 Cf. Schütze S., "Poussin interpretiert Tacitus 'le plus grand peintre de l'antiquité' Der “Tod des Germanicus' und sein historischer Kontext”, in Flemming V. von - Schütze S. (eds.), Ars naturam adiuvans. Festschrift für Matthias Winner (Mainz: 1996) (485-504) 495 . 


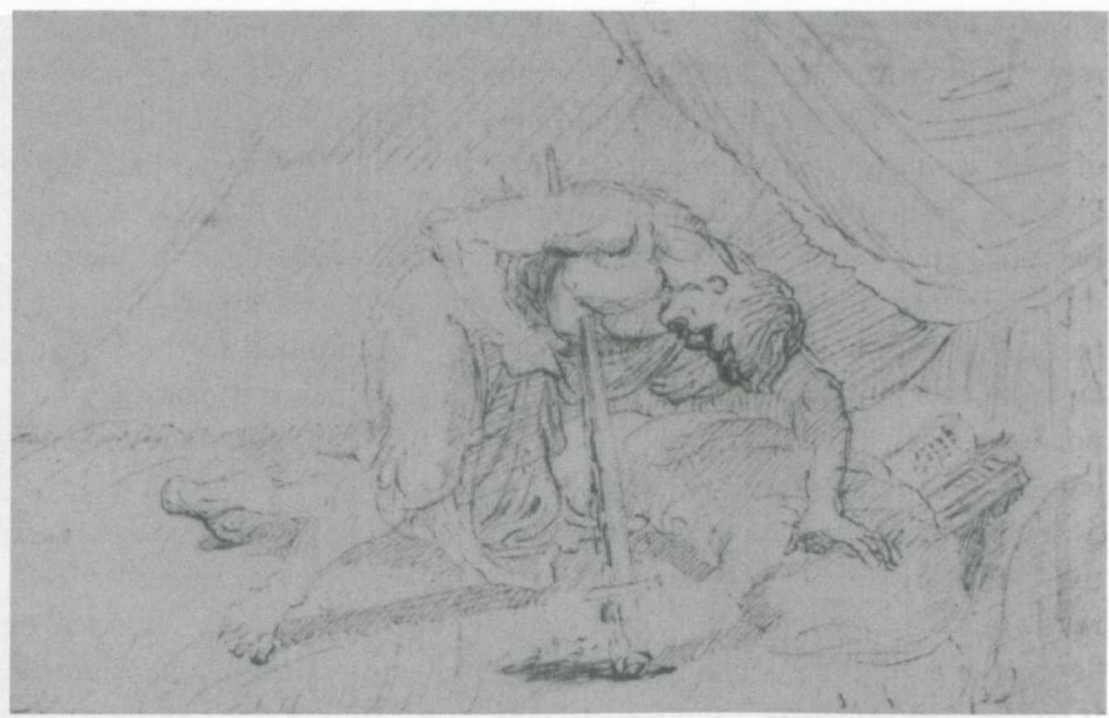

Fig. 4. Nicolas Poussin, Death of Cato, c. 1640. Windsor Castle, Royal Collections.

therefore, was not the only artist who, before painting his own work, read the relevant textual sources instead of just repeating already existing compositions or iconographic schemes. What makes Le Brun's picture special, in any case, is the fact that he moved away from representing the 'Death of Cato' within a large crowd of bystanders in full figure. In doing so, he appears to have been inspired by his life-long idol Nicolas Poussin. No painting by Poussin representing the suicide of Cato is known, but the artist experimented with the theme in a drawing today at Windsor Castle. In this undated sheet, all attention is focused on Cato, who has just stabbed himself in his bed with a large sword whose point can be seen protruding from his back [Fig. 4]. The open volume of the Phaidon lies next to him; there are no other figures. ${ }^{39}$

Poussin could easily have painted the 'Death of Cato' as a kind of classicist adaptation of the existing images of the event created by the Caravaggisti. Such a picture might have resembled the 'Death of Germanicus' that Poussin painted for Cardinal Francesco Barberini in 1628, in which the heroic death of a nephew of Emperor Tiberius in the presence of his wife

39 Rosenberg P. (ed.), Nicolas Poussin 1594-1665, exhibition catalogue (Paris: 1994) 273, cat. no. 85 . 
Agrippina, his children and several companions is shown..$^{40}$ The composition of Testa's 'Death of Cato' clearly stemmed from this work of Poussin, and Le Brun himself, if he had wished to, could have adapted the scheme of the 'Germanicus' to his own Cato painting.

However, as the cited examples of the 'Death of Cato' demonstrate, there were two basic options for the representation of such heroic deaths or self-killings in the first half of the Seicento: (1) life-size images with staffage figures or (2) half-length close-ups. The fact that both schemes existed side by side at the same time can be attributed to the taste for variation or simply to the different financial means of patrons and buyers, but such compositional variants must also have been regarded as expressions of different artistic attitudes toward the theme. ${ }^{41}$ In this context, it is tempting to assume that the two basic variants of 'Death of Cato' paintings were motivated by different analogies from literature, with the close-ups primarily addressing the emotional value of the event (analogy or inspiration: Seneca) and the full-figures providing a more complete or 'objective' rendering of the narrative (analogy: Plutarch). ${ }^{42}$ As far as visualisations of Seneca's approach to the story of Cato's death are concerned, Le Brun's picture turns out to be the most adequate and successful of all.

Leaving aside these elements, what else is special about Le Brun's painterly treatment of the Cato theme? One of the most characteristic aspects of the Arras picture is the fact that the Stoic hero is not represented in the act of committing suicide ${ }^{43}$ but as a 'sleeping' person. While the face of Le Brun's Cato appears to be a hybrid of Laocoon and Poussin's 'Saint Erasmus', ${ }^{44}$ the pose of his body closely resembles contemporary representations of the dead Christ, e.g. in the 'Lamentation' by Nicolas Poussin

40 Rosenberg, Nicolas Poussin 156-159, cat. no. 18.

41 Cf. Gianfreda S., Caravaggio, Guercino, Mattia Preti: Das halbfigurige Historienbild und die Sammler des Seicento (Emsdetten-Berlin: 2005) esp. 115-116.

42 A "Death of Cato" by Johann Heinrich Schönfeld shows the scene with mourners and bystanders represented in half-length figures (Pée H., Johann Heinrich Schönfeld. Die Gemälde (Berlin: 1971) 149-150, cat. no. 81). This picture can be interpreted as the result of the artist's deliberate attempt to combine emotional 'close-up' value with the broad narrative of a mass scene.

43 Guercino has represented Cato's suicide in a half-length close-up (Genoa, Palazzo Rosso) - Salerno L., I dipinti del Guercino (Rome: 1988) cat. no. 165, a preparatory study is in Dijon, Musée des Beaux-Arts. Cf. also Guercino's 'Suicide of Cleopatra' in the Palazzo Rosso, cat. no. 117 .

44 Poussin's 'Martyrdom of Saint Erasmus' has already been suggested as the model of Schönfeld's 'Cato' by Pée, Johann Heinrich Schönfeld 149, who argued that, in addition to the physiognomic similarities, both men died from intestinal injuries. 
today in Munich ${ }^{45}$ and Annibale Carracci's 'Pietà Farnese'46 - Le Brun himself has made such paintings. ${ }^{47}$ By introducing this Christian typus, he obviously tried to further increase the dignity and authority of Cato's example. ${ }^{48}$ One should keep in mind, however, that the Christian doctrine condemns suicide. Saint Augustine specifically mentioned and criticised the suicide of Cato as an invalid option for good Christians. ${ }^{49}$ Therefore, in spite of Neo-Stoicism being fashionable with artists in the seventeenth century, Le Brun can hardly have intended to glorify suicide in general.

The Baroque age, while sympathising with the Stoic doctrine, knew where to draw the line. A famous contemporary description of the last hours of Justus Lipsius (1547-1606), the protagonist of Neo-Stoicism, is a case in point. According to his vita published in 1613 , the dying Lipsius, when asked where he had left his Stoic 'constantia', replied: 'These are vane ideas' - and, pointing with his finger to the image of the crucified Christ next to his bed, he added most truly: 'This Is True Patience'. ${ }^{50}$ Although it is far from certain that Lipsius ever uttered these words, such an interpretatio Christiana enabled his contemporaries to understand an image of Cato as a reference to the most eminent of all 'exempla doloris', i.e. as a figure of the passion of the Son of God mirrored in the - outstanding suffering of a human being. ${ }^{51}$

45 Rosenberg (ed.), Nicolas Poussin 144, cat. no. 12.

46 Cf. Le Brun's 'Pietà' and 'Cato' illustrated on the same page in Chomer, "Charles Le Brun avant $1646^{\prime \prime} 99$.

47 See esp. Le Brun's 'Pietà' in the Musée du Louvre (Exposition Charles Le Brun 20, cat. no. 8).

48 In connection with Le Brun's 'Cato', one detail in Carracci's 'Pietà Farnese' (today in the Museo di Capodimonte, Naples) deserves special attention: the angel in the right foreground who is looking at the spectator while touching the Crown of Thorns with an expression of grief and suffering, signifies both the brutality of Christ's passion and suggests the preferred mode of reception, i.e. 'compassio': 'per indurre lo spettatore a partecipare al dolore infinitamente maggiore sofferto da Cristo durante la Passione - una sofferenza ormai conclusa, ma che occorre far rivivere nell'animo di chi guarda per fargli cogliere il pieno significato del Sacrificio di Cristo e del dolore della Vergine', Carel van Tuyll, in Benati D. - Riccòmini E. (eds.), Annibale Carracci, exhibition catalogue (Rome: 2006) 376 . Although Le Brun decided to leave out such a figure, he moved the body of Cato so close to the picture plane that the spectator inevitably feels concerned.

49 Augustinus, De civitate Dei, I, 23, cf. Eckert, Weltanschauung und Selbstmord 179.

50 ' 'Vana sunt ista.' - digitoque in Christi crucifici imaginem, lectulo astantem, intento, HAEC VERA EST PATIENTIA, verissime subiecit.' Lipsius Iustus, Lipsi Opera Omnia, Editio Secunda (Antwerp: 1613) 133-134, quoted after Hess, "Der Tod des Seneca" 224.

${ }^{51}$ Cf. Ettlinger L.D., "Exemplum Doloris: Reflections on the Laocoon Group", in Meiss M. (ed.), De Artibus Opuscula XL. Festschrift Panofsky (New York: 1961) (120-126) 126: "That is why theologians during the Counter Reformation could recommend the Laocoon to those who had to make images of the Passion of Christ, of suffering saints and martyrs. 
In the seventeenth century, Le Brun's painting could also be understood without these specific religious allusions if one subscribed to the maxim of Aristotle that looking at images of pain and fear increases the viewer's capability to suffer such pain and fear himself. ${ }^{52}$ In addition to that, Le Brun (thus aligning himself with stoic psychagogy) ${ }^{53}$ employed and subtly redefined a central element of Cato's story: the open book in the foreground is not just an attribute needed for the identification of the painting's subject, but, rather, an important means employed for the work's appellative function. Looking at this book, the beholder realises that he is supposed to 'read' this picture as a magistral stoic text - in a way not unlike which, according to Tacitus (Annales XV,62), the dying Seneca announced to his friends that, as he was not allowed to write down his last will, he would leave them the image of his life ('imaginem vitae'). Regarding the Arras painting, one can even assume that the blood on the sheets between the book and Cato's wound was intended to visually connect the philosophical text with the (yet) living personification of 'applied philosophy'.

It comes as no surprise that images of the deaths of Cato and Seneca were often created or combined as pendants in the Baroque age (regardless of the fact that Cato at the time of his death was much younger than Seneca).${ }^{54}$ However, Le Brun must have been aware of the fact that such

Not only academic training but true understanding of the power of this exemplum may have influenced French artists of the seventeenth century when they turned the suffering Laocoon into a model for a dying Cato'. Leaving aside the suicide of Pietro Testa (cf. note 27), another famous self-killing in Seicento Rome comes to mind that may well have been modeled on the example of the Uticensis: the suicide of Borromini - cf. "Borromini and Stoicism" = Appendix IV, 174-176, to Wittkower R., "Francesco Borromini, his character and life", in Idem, Studies in the Italian Baroque (London: 1975) 153-176 (first published as "Francesco Borromini: personalità e destino", in Studi sul Borromini: atti del Convegno promosso dall'Accademia Nazionale di San Luca (Rome: 1970-1972) vol. I, 17-48), and Thelen H., "Francesco Borromini: Bemerkungen zur Persönlichkeit", in Staccioli G. - OsolsWehden I. (eds.), Come l'uom s'etterna: Beiträge zur Literatur-, Sprach-und Kunstgeschichte Italiens und der Romania (Berlin: 1994) 264-294.

52 Cf. Hess, "Der Tod des Seneca" 224: 'Die Kategorie der consolatio, die sich in der consideratio des Todesbildes und seiner atrocitas einstellen soll, führt über die von den Affekten der commiseratio und compassio geschärfte Meditation zur praemeditatio, die auch den eigenen Tod reflektiert'.

53 Cf. Zimmermann B., "Philosophie als Psychotherapie: Die griechisch-römische Consolationsliteratur", in Neymeyr B. - Schmidt J. - Zimmermann B. (eds.), Stoizismus in der europäischen Philosophie, Literatur, Kunst und Politik. Eine Kulturgeschichte von der Antike bis zur Moderne (Berlin-New York: 2008), vol. I, 193-213.

54 Cf., among others, pendants by Luca Giordano (Ferrari - Scavizzi, Luca Giordano 822), Sebastiano Conca (Oberreuter-Kronabel, Der Tod des Philosophen, Figs. 52 and 57 ) and Giambattista Cignaroli (Geiger, "Giambettino Cignaroli's Death of Cato and of Socrates"). 
analogies of text and image could not be carried too far: a long time before Lessing, he realised that images, in which the narrative flux has been halted and synthesised to represent the essence of a story, own a stronger, more persistant power to convince and impress their message on the beholder than written or printed texts that are being consulted for mere information or entertainment. Stoic authors as Seneca argued on a rational level, ${ }^{55}$ but they knew that their struggle against fear had to address human faculties other than the intellect. In this sense, Seneca's 'exempla quibus confirmeris' (Seneca, Epistulae 24,3) were meant to provide longterm support for the emotional faculties of human nature that need to be convinced or persuaded over and over again. ${ }^{56}$ It is significant, therefore, that Le Brun, who in his later career represented and theorised the Passions de l'âme like no other artist of his era, decided to depict a moment of Cato's story not chosen by any of his colleagues, a moment in which what little there is of narrative has been relegated to the dark background and all traces of emotional expression on the hero's face are absent. This lack of expression guaranteed the image's functioning as a reflecting space on which the beholder could project his acquaintance with the stories of Cato's suffering and find constant encouragement for his personal Stoic convictions and aspirations. In combination with the open book, it also served as a constant reminder to study the writings of ancient philosophy in order to fully understand the intellectual basis of Cato's political and moral virtue. As such, Le Brun's picture represented to its unknown first owner - as Michel de Montaigne put it ${ }^{57}$ - a 'patron chosen by nature to demonstrate the heights that human virtue and steadfastness can reach' ('patron que nature choisit pour montrer jusques où l'humaine vertu et fermeté pouvoit atteindre').

Charles Le Brun himself may have painted a 'Death of Seneca', as a picture of this subject is mentioned in an early source: Scudéry G. de, Le Cabinet de Mr de Scudéry, Gouverneur de Nostre-Dame de la Garde (Paris, Augustin Courbé: 1646) 212, cf. Olson T.P., Poussin and France. Painting, Humanism, and the Politics of Style (New Haven-London: 2002) 202.

55 Cf. Seneca, Epistulae 24,2: 'Intelleges profecto aut non magnum aut non longum esse quod metuis'.

56 For Rubens' theories regarding the 'leidenschaftliches Erleben' of paintings cf. Heinen U., "Peter Paul Rubens - Barocke Leidenschaften", in Büttner N. - Heinen U. (eds.), Peter Paul Rubens: Barocke Leidenschaften, exhibition catalogue (Munich: 2004) 28-38, esp. 30-31.

57 Montaigne Michel de, Essais [1580-1588], ed. M. Rat (Paris: 1962) 261; cf. Besslich, "Cato als Repräsentant stoisch formierten Republikanertums" 376-378. 


\section{Selective Bibliography}

ACAdÉmie de France A Rome (ed.), Roma 1630. Il trionfo del pennello, exhibition catalogue (Milan: 1994).

Benati D. - Riccòmini E. (eds.), Annibale Carracci, exhibition catalogue (Rome: 2006).

BEssLich B., "Cato als Repräsentant stoisch formierten Republikanertums von der Antike bis zur Französischen Revolution", in Neymeyr B. - Schmidt J. - Zimmermann B. (eds.), Stoizismus in der europäischen Philosophie, Literatur, Kunst und Politik. Eine Kulturgeschichte von der Antike bis zur Moderne (Berlin-New York: 2008), vol. I, 365-392.

Brown R.M., The Art of Suicide (Chicago: 2001).

CANCIK H., Untersuchungen zu Senecas Epistulae morales (Hildesheim: 1967).

Charles Le Brun 1619-169o, peintre et dessinateur, exhibition catalogue Paris (Paris: 1963).

Сномеr G., "Charles Le Brun avant 1646: Contribution aux problèmes de sa formation et de ces œuvres de jeunesse", Bulletin de la Société de l'histoire de l'art français (1977) 93-107.

ConTini R. (ed.), Pracht und Pathos: Meisterwerke der Barockmalerei aus dem Palazzo Bianco in Genua, exhibition catalogue (Berlin-Milan: 2003).

Cropper E., Pietro Testa 1612-1650. Prints and Drawings, exhibition catalogue (Aldershot: 1988).

ECKert H.H., Weltanschauung und Selbstmord bei Seneca und den Stoikern (PhD thesis, Tübingen: 1951).

ETTLINGER L.D., "Exemplum Doloris: Reflections on the Laocoon Group”, in Meiss M. (ed.), De Artibus Opuscula XL. Festschrift Panofsky (New York: 1961) 120-126.

FEHRLE R., Cato Uticensis (Darmstadt: 1983).

Ferrari O. - ScAvizzi G., Luca Giordano. L'opera completa (Naples: 1992).

Fischbacher F., Matthias Stomer. Die sizilianischen Nachtstücke (Frankfurt: 1993).

GADY B., L'ascension de Charles Le Brun. Liens sociaux et production artistique (Paris: 2010).

Gareau M., Charles Le Brun. First Painter to King Louis XIV (New York: 1992).

GEIGER J., "Giambettino Cignaroli's Death of Cato and of Socrates", Zeitschrift für Kunstgeschichte 59 (1996) 270-278.

Gianfreda S., Caravaggio, Guercino, Mattia Preti: Das halbfigurige Historienbild und die Sammler des Seicento (Emsdetten-Berlin: 2005).

GOAR R.J., The legend of Cato Uticensis from the first century B.C. to the fifth century A.D. (Brussels: 1987).

Grimal P., Seneca. Macht und Ohnmacht des Geistes (Darmstadt: 1978).

HaDOт I., Seneca und die griechisch-römische Tradition der Seelenleitung (Berlin: 1969).

Heinen U., "Peter Paul Rubens - Barocke Leidenschaften", in Büttner N. - Heinen U. (eds.), Peter Paul Rubens: Barocke Leidenschaften, exhibition catalogue (Munich: 2004) 28-38.

Hess G., "Der Tod des Seneca: Ikonographie - Biographie - Tragödientheorie", Jahrbuch der Deutschen Schillergesellschaft 25 (1981) 196-228.

La peinture française aux XVlle et XVllle siècles: Dunkerque, Valenciennes, Lille, exhibition catalogue, Trésors des Musées du Nord de la France 4 (Lille: 1980).

LipsIUs Justus, Lipsi Opera Omnia, Editio Secunda (Antwerp: 1613).

MAI E. - Repp-Eckert A. (eds.), Triumph und Tod des Helden, exhibition catalogue (Cologne: 1987).

MAURACH G., Der Bau von Senecas Epistulae Morales (Heidelberg: 1970).

Montagu J., The Expression of the Passions: The Origin and Influence of Charles Le Brun's Conference sur l'expression générale et particulière (New Haven-London: 1994).

Montaigne Michel de, Essais [1580-88], ed. M. Rat (Paris: 1962).

Nrvelon C., Vie de Charles Le Brun et description détaillée de ses ouvrages. Édition critique et introduction par Lorenzo Pericolo (Geneva: 2004).

Oberreuter-Kronabel G., Der Tod des Philosophen (Munich: 1986). 
Olson T.P., Poussin and France. Painting, Humanism, and the Politics of Style (New HavenLondon: 2002).

PÉE H., Johann Heinrich Schönfeld. Die Gemälde (Berlin: 1971).

Rosenberg P. (ed.), Nicolas Poussin 1594-1665, exhibition catalogue (Paris: 1994).

SAINT-Georges G. de, Mémoires inédits sur la vie et les ouvrages des membres de l'Académie royale de peinture et de sculpture, (Paris: 1854), vol. I.

SALERNO L., I dipinti del Guercino (Rome: 1988).

Schütze S., "Poussin interpretiert Tacitus 'le plus grand peintre de l'antiquité' - Der 'Tod des Germanicus' und sein historischer Kontext”, in Flemming V. von - Schütze S. (eds.), Ars naturam adiuvans. Festschrift für Matthias Winner (Mainz: 1996) 485-504.

Scudéry Georges de, Le Cabinet de Mr de Scudéry, Gouverneur de Nostre-Dame de la Garde (Paris, Augustin Courbé: 1646).

Thelen H., "Francesco Borromini: Bemerkungen zur Persönlichkeit", in Staccioli G. Osols-Wehden I. (eds.), Come l'uom s'etterna: Beiträge zur Literatur-, Sprach- und Kunstgeschichte Italiens und der Romania (Berlin: 1994) 264-294.

Thuillier J. (ed.), Jacques Stella 1596-1657, exhibition catalogue (Paris: 2006).

WEIgERT R.-A., "L'inventaire après décès de Charles Le Brun, premier peintre de Louis XIV (169o)", Gazette des Beaux-Arts 96 (1954) 339-354, 371-376.

WITTKOWER R., Studies in the Italian Baroque (London: 1975).

, "Francesco Borromini, his character and life", in Idem (ed.), Studies in the italian Baroque (London: 1975) 153-176.

Zimmermann B., "Philosophie als Psychotherapie: Die griechisch-römische Consolationsliteratur", in Neymeyr B. - Schmidt J. - Zimmermann B. (eds.), Stoizismus in der europäischen Philosophie, Literatur, Kunst und Politik. Eine Kulturgeschichte von der Antike bis zur Moderne (Berlin-New York: 2008), vol. I, 193-213. 